\title{
Technophobia and Patriotic Pride
}

As long as there has been technology, there has been someone to resist it. In 1811, a group known as the Luddites tried to prevent the mechanization of the textile industry in England by vandalizing the proliferating mechanical looms. Over a few years, their activities grew into large riots that eventually had to be quelled through martial law and even the imposition of capital punishment. Civil disorder is not so widely or aggressively used today-imagine, if you will, the prospect of vacuum tube manufacturers' skilled labor pools attacking semiconductor fabs with sticks and stones. Of course, that would have happened in the 1960s and would have been completely overshadowed by other kinds of riot, at least in the United States.

The Luddites were motivated by economics, as they saw their traditional sources of income eroded. Nowadays, technophobia seems to be focused on threats to our lifestyle as much as our economic well-being, and is consequently revealing about our self-image. Nothing focuses debate in the North American "land of the free" like a proposal to build a new nuclear power facility within neutron range of any particular community. In the European home of liberté, egalité, et fraternité, in contrast, nuclear power is much less controversial, and some $60 \%$ of all electricity is generated from that source. Conversely, in France, so tolerant of nuclear power, genetically modified foods are apt to cause public outcry and even marching in the streets, while most Americans are unaware or do not seem to care that much of what they eat comes to their tables with manipulated DNA.

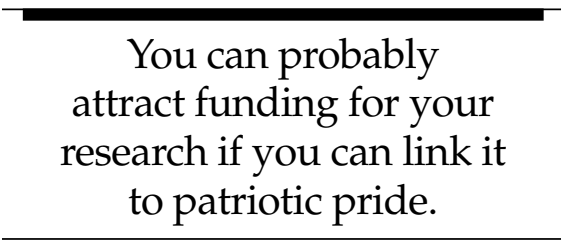

Why is it that nuclear power is acceptable in France and unacceptable in America, but genetic modification of food is embraced in America and anathema in France? Perhaps it is because in the world league of gastronomy, France is the undisputed leader, and who but the Americans are the greatest gourmands of energy? Some points of cultural pride are selfmockingly sloganized, but the really serious ones remain unstated: "Don't mess with Texas," (if you are a Texan), never, ever, fool with a Frenchman's food or adulterate an American's energy. We guard those things that are most important to us, and we guard them especially from the mysteriously invisible forces of science.

When national character is at stake, sense and reason take no part in the debate; but what does this imply for other scientific ventures? Does nanotechnology have a reliable place in a nation where everything is "megasized" or should we be more concerned about public outcry over cosmology, the very science of the largest length scales? In reality, Americans care more about very large things than very small ones-I can still remember the public outrage when a work crew felled a tree in my community, because we lost the bragging rights for the largest of its kind in the country. At the time of writing, there is actually some public concern about the future of our greatest cosmological experimental tool, the Hubble Space Telescope, and the debate is a matter of budgetary choice between continuing to support the Hubble and pursuing another point of American pride, manned space exploration.

You can probably attract funding for your research if you can link it to patriotic pride, but be warned: To avoid public approbation of your research, take care to avoid topics that in any way threaten to alter national traditions. Don't try to make a thermoelectric beer cooler if you live in Germany. Don't try to control the rainfall if you live in England. And if you do accept these risks, and brave the gilded path of funding your research by appealing to national honor, remember Samuel Johnson's observation that "Patriotism is the last refuge of a scoundrel."

Alex KING 